\title{
ADGRF1 wt Allele
}

National Cancer Institute

\section{Source}

National Cancer Institute. ADGRF1 wt Allele. NCI Thesaurus. Code C113544.

Human ADGRF1 wild-type allele is located in the vicinity of $6 \mathrm{p} 12.3$ and is approximately 45

kb in length. This allele, which encodes adhesion G-protein coupled receptor F1 protein,

has an unknown cellular function. Mutations in this gene are associated with both

prostate cancer and prostatitis. 